\section{MENINGKATKAN KESIAPAN UJI KOMPETENSI NERS MELALUI BIMBINGAN INTENSIF}

\author{
Improving The Readiness of NERS Competence Test Through Intensive Guidance \\ Rachmat Chusnul Choeron', Wahyu Dini Metrikayanto ${ }^{1}$
}

Dosen Fakultas Ilmu Kesehatan Universitas Tribhuwana Tunggadewi malang

\section{Riwayat artikel \\ Diajukan: 3 Maret 2020 \\ Diterima: 28 Maret 2020}

\section{Penulis Korespondensi: \\ - Rachmat Chusnul \\ Choeron \\ - Universitas Tribhuwana Tunggadewi Malang}

\section{brputra88.bp@gmail.co}

\section{$\mathrm{m}$}

\section{Kata Kunci:}

Bimbingan intensif, kesiapan uji kompetensi, ners

\begin{abstract}
Abstrak
Pendahuluan: Angka kelulusan uji kompetensi (ukom) ners secara nasional dari tahun ke tahun masih tergolong rendah. Berbagai cara ditempuh oleh perguruan tinggi untuk meningkatkan kemampuan mahasiswanya dalam menghadapi ukom. Tujuan penelitian ini ialah untuk membuktikan efektivitas bimbingan intensif terhadap kesiapan mahasiswa dalam menghadapi ukom ners. Desain penelitian menggunakan one group pre-post test design. Populasi pada penelitian ini ialah mahasiswa ners yang telah diyudisum pada periode akhir tahun ajaran 2018-2019 Fakultas Ilmu Kesehatan Universitas Tribhuwana Tunggadewi Malang. Sampel sebanyak 60 responden diambil dengan teknik random sampling. Data dikumpulkan menggunakan lembar evaluasi yang terdiri dari 180 pertanyaan vignette yang disusun oleh tim yang tersertifikasi item development dan item review. Data diuji menggunakan uji paired t test dengan $\alpha=0,05$. Hasil penelitian menunjukkan bahwa kesiapan mahasiswa dalam menghadapi ukom ners sebelum diberikan bimbingan intensif berada pada rerata 36,00 $(\mathrm{SD}=09,36)$, kesiapan mahasiswa dalam menghadapi ukom ners setelah diberikan bimbingan intensif berada pada rerata 45,89 $(\mathrm{SD}=6,83)$ dan bimbingan intensif terbukti efektif meningkatkan kesiapan mahasiswa dalam menghadapi ukom ners $(\mathrm{p}=0,000)$. Bimbingan intensif sangat penting diberikan kepada mahasiswa untuk meningkatkan kesiapan menghadapi ukom sehingga angka kelulusan ukom dapat meningkat.
\end{abstract}

\begin{abstract}
Introduction Ners national competency test (ukom) passing rates from year to year is still relatively low. Various ways taken by universities to improve the ability of students in dealing with ukom. The purpose of this study is to prove the effectiveness of intensive guidance on students' readiness in dealing with student care. The study design used one group pre-post test design. The population in this study were nurses who had graduated in the final period of the 2018-2019 school year, Faculty of Health, University of Tribhuwana Tunggadewi Malang. A sample of 60 respondents were taken by random sampling technique. Data was collected using an evaluation sheet consisting of 180 vignette questions compiled by a team that was certified with item development and item review. Data were tested using paired t test with $\alpha=0.05$. The results showed that the readiness of students in facing nurses before giving intensive guidance was at a mean of 36.00 ( $\mathrm{SD}=09.36)$, the readiness of students in dealing with nurses after being given intensive guidance was at a mean of $45.89(\mathrm{SD}=6.83)$ and intensive guidance has been proven effective in increasing students' readiness in facing nurses $(p=0,000)$. Intensive guidance is very important given to students to increase their readiness to face ukom so that graduation rates can increase.
\end{abstract}

\section{PENDAHULUAN}

Uji kompetensi (ukom) ners nasional merupakan uji yang digunakan untuk menstandardisasi kompetensi perawat
Indonesia saat ini. Perawat dikatakan kompeten jika lulus ukom nasional. Untuk dapat meningkatkan kompetensi perawat, Asosiasi Institusi Pendidikan Ners Indonesia 
(AIPNI) mengeluarkan beberapa himbauan kepada anggotanya untuk mempersiapkan dan membina mahasiswanya sehingga siap untuk mengikuti ukom nasional dengan hasil yang maksimal (lulus) (AIPNI, 2019). Akan tetapi, angka kelulusan ukom nasional perawat (ners) dari tahun ke tahun masih cukup rendah dan terus menurun dari tahun 2016 hingga akhir tahun 2018. Sementara jumlah peserta ukom ners dari tahun ke tahun terus bertambah. Hal ini dikarenakan peserta yang tidak lulus ukom dari tahun ke tahun terus bertamah dan menumpuk pada periode selanjutnya (Dikti, 2019).

Berdasarkan data yang didapatkan dari Direktorat Jenderal Pendidikan Tinggi (Dirjendikti) pada tahun 2016 peserta ukom ners sebanyak 28.812 peserta dengan angka kelulusan 53,46\%. Pada tahun 2017 peserta ukom ners meningkat tajam hingga 42.068 peserta dengan angka kelulusan 50,58\%. Dan pada tahun 2018 peserta ukom sebanyak 50.058 dengan angka kelulusan 50,38\% (Dikti, 2019). Sementara itu, hasil ukom ners di Universitas Tribhuwana Tunggadewi Malang dari tahun ke tahun juga masih rendah. Pada tahun 2018 angka kelulusannya mencapai 41,92\% (Dikti, 2019).

Rendahnya kelulusan ukom ners dipengaruhi oleh beberapa faktor, diantaranya ialah try out yang diikuti sebelum mengikuti ukom, indeks prestasi kumulatif (IPK) dan gaya belajar mahasiswa (Abdillah, 2016). Selain itu, tidak fokus dalam belajar, kebingungan dan kecemasan dalam menghadapi ukom, serta ketidaktahuan sistem kerja CBT (computerized based test) juga menjadi hambatan kelulusan peserta ukom (Kholifah \& Kusumawati, 2016). Pendapat lain juga mengatakan hasil try out nasional, IPK akademik dan keaktifan mahasiswa juga mempengaruhi kelulusan ukom ners (Lukmanulhakim \& Pusporini, 2018). Selain IPK akademik, sarana dan prasarana juga turut mempengaruhi kelulusan ukom ners (Syah, 2017).

Institusi memiliki peran penting dalam mempersiapkan kelulusan mahasiswanya dari ukom. Persiapan tersebut dapat dimulai sejak semester awal. Beberapa cara yang dapat diterapkan ialah dengan menerapkan ujian tengah semester dan ujian akhir semester dengan menggunakan soal vignette dan sudah terintegrasi dengan komputer atau online. Sehingga mahasiswa tidak merasa asing lagi dengan soal-soal yang berbasis problem solving. Untuk mendukung hal tersebut, maka dosen pengajarnya juga harus dibekali dengan kemampuan item development dan item review. Selain itu, bimbingan secara khusus untuk persiapan ukom juga perlu dilakukan institusi guna memantapkan kesiapan mahasiswa. Berbagai macam metode bimbingan dapat dilakukan, baik secara online maupun offline.

\section{METODE PENELITIAN}

Desain penelitian menggunakan one group pre-post test design dengan populasi mahasiswa Fakultas Ilmu Kesehatan Universitas Tribhuwana Tunggadewi Malang yang telah menyelesaikan program profesi ners pada bulan Desember 2018. Sampel sebanyak 60 responden diambil secara acak. Responden yang terpilih diberi soal ujian vignette sebanyak 180 soal yang dikerjakan secara online. Selama pengerjaan soal, responden dikumpulkan di ruang kuliah dan dijaga oleh pengawas. Pengerjaan soal menggunakan smartphone masing-masing responden. Soal dikerjakan selama 180 menit. Soal disusun oleh tim penyusun soal yang telah tersertifikasi item development dan item review yang merujuk pada materi pokok dalam buku Sinersi. Soal terdiri dari 8 departemen. Setelah responden mengerjakan soal, responden diberi intervensi berupa bimbingan intensif. Bimbingan dilakukan setiap hari (senin-jumat) mulai pukul 08.00 14.00 WIB selama 2 minggu dengan metode problems solving, yaitu pemecahan kasuskasus yang sering muncul dalam soal ukom. Peserta yang tidak mengikuti bimbingan secara penuh tidak diikutkan pada ujian vignette selanjutnya (post-test). Data 
dianalisis menggunakan uji paired $t$ test dengan $\alpha=0,05$.

Syarat pembimbing ialah berijasah minimal S2 Keperawatan dan telah mengikuti pelatihan item development dan item review. Sebelum melakukan proses bimbingan dilakukan breafing untuk persamaan persepsi dan metode bimbingan.

\section{HASIL DAN PEMBAHASAN}

Tabel 1 Hasil analisis efektivitas bimbingan insentif terhadap kesiapan mahasiswa dalam menghadapi ukom ners

\begin{tabular}{lcc}
\hline \multicolumn{1}{c}{ Variabel } & Mean (SD) & $\mathrm{p}$ \\
\hline Pre-test & $36,00(9,36)$ & 0 \\
Post-test & $45,89(6,83)$ & \\
\hline
\end{tabular}

Berdasarkan tabel diatas menunjukkan bahwa kesiapan mahasiswa dalam menghadapi ukom ners sebelum diberikan bimbingan intensif berada pada rerata 36,00 $(\mathrm{SD}=09,36)$ dan kesiapan mahasiswa dalam menghadapi ukom ners setelah diberikan bimbingan intensif berada pada rerata 45,89 $(\mathrm{SD}=6,83)$. Selain itu, hasil penelitian ini juga membuktikan bahwa bimbingan intensif efektif meningkatkan kesiapan mahasiswa dalam menghadapi ukom ners $(\mathrm{p}=0,000)$.

Kesiapan mahasiswa dalam menghadapi ukom ners sebelum diberikan bimbingan intensif

Hasil penelitian menunjukkan bahwa kesiapan mahasiswa dalam menghadapi ukom sebelum diberikan bimbingan intensif masih jauh dari harapan untuk lulus ukom. Hal ini terjadi karena mahasiswa masih belum terpapar dengan soal-soal ukom dan belum pernah mendapatkan informasi mengenai strategi-strategi dalam menyelesaikan soalsoal ukom, walaupun dalam proses akademiknya mahasiswa telah diarahkan pada pemecahan kasus. Rendahnya kesiapan mahasiswa dalam mengikuti ukom seharusnya menjadi perhatian khusus oleh institusi, karena kesiapan dan kemampuan mahasiswa sangat tergantung pada proses penyelenggaraan pendidikan. Semakin baik mutu proses pendidikannya, maka semakin baik pula mutu lulusannya (learning outcomes). Akan tetapi sistem kendali mutu proses pendidikan ners di Indonesia masih terus berbenah dan belum berjalan sepenuhnya, khususnya kendali mutu internal (Masfuri, 2012). Hal ini senada dengan hasil penelitian sebelumnya yang menyatakan bahwa IPK akademik memiliki hubungan yang erat dengan kelulusan ukom. Semakin tinggi IPK semakin tinggi pula potensi untuk lulus ukom (Abdillah, 2016; Lukmanulhakim \& Pusporini, 2018; Syah, 2017).

Kesiapan mahasiswa dalam menghadapi ukom menjadi permasalahan yang harus dipecahkan oleh institusi. Pemecahan masalah tersebut harus dimulai dari proses pembelajaran selama mahasiswa menempuh pendidikan. Institusi perlu mengidentifikasi karakteristik mahasiswanya, dan terus berinovasi dan mengujicobakan berbagai metode pembelajaran yang efektif serta menetapkan metode pembelajaran yang efektif tersebut. Proses pembelajaran juga harus dimonitor dan dievaluasi guna menjamin proses pembelajaran berjalan sesuai dengan ketetapan. Dengan demikian kesiapan dan kemampuan mahasiswa dalam menghadapi ukom dapat menjadi lebih baik.

Kesiapan mahasiswa dalam menghadapi ukom ners setelah diberikan bimbingan intensif

Hasil penelitian menunjukkan bahwa kesiapan mahasiswa dalam menghadapi ukom setelah diberikan bimbingan intensif mengalami peningkatan yang signifikan. Paparan soal-soal vignette dan strategi pemecahan kasus memberikan pemahaman tersendiri bagi mahasiswa dalam menyelesaikan kasus. Hal ini senada dengan hasil penelitian seelumnya yang mengatakan bahwa try out yang diikuti sebelumnya oleh mahasiswa turut berperan dalam kelulusan ukom. Mahasiswa yang lulus try out khususnya try out nasional yang diselenggarakan oleh APINI memberikan dampak positif terhadap kelulusan ukom 
(Abdillah, 2016; Lukmanulhakim \& Pusporini, 2018). Try out merupakan salah satu cara untuk meningkatkan kemampuan mahasiswa dalam menghadapi ukom. Namun, try out berbeda dengan bimbingan intensif, karena dalam try out mahasiswa hanya dilatih untuk mengerjakan soal-soal, tidak diajarkan bagaimana cara memecahkan soal. Bimbingan intensif penting diberikan oleh institusi kepada mahasiswa sebelum pelaksanaan ukom nasional. Melalui bimbingan intensif mahasiswa tidak hanya diajarkan bagaimana cara memecahkan kasus-kasus yang ada dalam soal, tetapi juga bagaimana menemukan dan menerapkan pola penyelesaian masalah dari masing-masing departemen yang diujikan. Pola-pola pemecahan masalah merupakan hal terpenting yang harus dikuasai oleh mahasiswa, karena setiap departemen yang diujikan memiliki pola yang berbeda-beda.

Efektivitas bimbingan insentif terhadap kesiapan mahasiswa dalam menghadapi ukom ners

Hasil penelitian menunjukkan bahwa ada pengaruh yang sangat signifikan bimbingan intensif terhadap kesiapan mahasiswa dalam menghadapi ukom nasional. Adanya peningkatan kemampuan mahasiswa setelah diberi bimbingan intensif mengandung arti bahwa bimbingan intensif sangat penting diberikan kepada mahasiswa sebelum mengikuti ukom nasional. Hal ini sesuai dengan yang diamanatkan oleh AIPNI bahwa setiap institusi penyelenggara pendidikan ners untuk mengadakan pembinaan kepada mahasiswanya guna mempersiapkan kemampuannya menghadapi ukom, baik dalam bentuk latihan soal maupun lainnya (APINI, 2018; APINI Regional XI, 2018). Berbagai metode atau cara dapat ditempuh institusi untuk meningkatkan angka kelulusan mahasiswa dari ukom nasional. Salah satu cara yang terbukti efektif ialah dengan memberikan bimbingan secara intensif minimal selama 2 minggu. Semakin kompleks kemampuan kognitif mahasiswa, maka diperlukan waktu yang lebih lama. Bimbingan intensif yang dimaksud ialah dengan memberikan stimulasi berupa soal dan dibahas dalam kelas melalui pendekatan yang komprehensif. Bimbingan harus dilakukan oleh dosen yang berpengalaman dalam pembuatan soal-soal ukom. Sehingga dalam penyampaiannya dapat lebih terarah dan lebih mendalam.

\section{KESIMPULAN}

Ukom ners nasional merupakan standardisasi kompetensi bagi perawat di Indonesia. Angka kelulusan yang masih sangat rendah memicu berbagai macam permasalahan. Oleh sebab itu, kemampuan mahasiswa untuk mengikuti ukom harus dipersiapkan sejak awal, yaitu saat mahasiswa masih menempuh pendidikan. Namun, jika setelah mahasiswa selesai menempuh pendidikan dan hal tersebut dirasa belum cukup, maka dapat dilakukan persiapanpersiapan lain. Salah satu jalan yang bisa ditempuh ialah dengan memberikan bimbingan intensif. Bimbingan intensif telah terbukti meningkatkan kesiapan mahasiswa dalam menghadapi ukom ners nasional.

\section{SARAN}

Institusi pendidikan ners memiliki tanggung jawab besar dalam mendukung kelulusan mahasiswanya dari ukom. Sehingga institusi diharapkan mau dan mampu memberikan bimbingan secara intensif kepada mahasiswanya guna meningkatkan angka kelulusan ukom dan meningkatkan kualitas lulusan.

\section{DAFTAR PUSTAKA}

Abdillah, A. (2016). Analisis faktor-faktor yang mempengaruhi kelulusan uji kompetensi ners Indonesia. Jurnal Penelitian Administrasi Publik, Vol. 2(2): Hal. 373-380 
AIPNI. (2018). Surat Edaran Try Out UKOM. Diakses dari http://aipni-ainec.org pada tanggal 5 Januari 2018

AIPNI Regional XI. Surat Edaran Try Out UKOM. Diakses dari http://aipnijatim.blogspot.com pada tanggal 5 Januari 2019

DIKTI. (2019). Data Statistik Pendaftar Lulus dan Tidak Lulus. Diakses dari Uji Kompetensi Ners: http://ukners.dikti.go.id/ pada tanggal 5 Januari 2019

Kholifah, S \& Kusumawati, W. (2016). Hambatan lulusan ners dalam menghadapi uji kompetensi Health Science, Vol. 7(1): Hal. 40-47

Khoiriyah, S. \& Indriyani, F. (2017). Peran perawat dalam Uji Kompetensi Internasional NCLEX RN. Jurnal Ilmiah Kesehatan, Hal. 66-77

Lukmanulhakim \& Puspitorini, LS. (2018). Analisis faktor yang mempengaruhi capaian kelulusan uji kompetensi ners Indonesia Program Profesi Ners. Jurnal Cakrawala Pendidikan, Vol. 2(2): Hal. 306-320

Masfuri. (2012). Pedoman Latihan Uji Kompetensi Perawat. Jakarta: Pengurus Pusat PPNI

Syah, DZR. (2017). Faktor-faktor yang mempengaruhi kelulusan uji kompetensi mahasiswa profesi ners STIKes Jenderal Ahmad Yani Yogyakarta. Jurnal Wacana Kesehatan, Vol. 2(2): Hal. 180-190 